environmental conditions in buildings. The award is made by the Heating and Ventilating Contractors Association and has a value of $£ 800$ per annum. The award would be made, in the first instance, for a period of one academic year, but is renewable subject to satisfactory progress. Holders of the scholarship would be permitted to submit their work for a high degree where university regulations permit. Further information and a form of application can be obtained from the Secretary and Clerk to the Governors, National College for Heating, Ventilating, Refrigeration, and Fan Engineering, Borough Polytechnic, Borough Road, London, S.E.1.

\section{Chelsea College of Science and Technology}

IN accordance with the decision of the University Grants Committee, the Governing Body of Chelsea College of Science and Technology, with the approval of the Academic Advisory Committee, has in anticipation of the grant of University Status to the College conferred the title of professor on the following heads of Departments: Dr. A. H. Beckett (pharmacy), Dr. S. E. Dicker (physiology and pharmacology), Dr. J. F. J. Dippy (chemistry), Dr. K. W. Keohane (physics), Mr. A. E. Ludlam (mathematics), Dr. R. D. Purchon (botany and zoology). In addition, the title of reader has been conferred on Dr. W. E. Smith (geology).

\section{University News:}

East Anglia

DR. D. C. Chamrenex, at present lecturer in physics in the University of Birmingham, has been appointed lecturer in physics.

London

DR. JACK Trzard, of the Social Psychiatry Research Unit of the Medical Research Council at the Institute of Psychiatry, has been appointed to the chair of child development at the Institute of Education. The following have been appointed to readerships: Dr. P. W. M. Jacobs (physical chemistry at Imperial College of Science and Technology); Dr. K. B. Roberts (physiology at the London Hospital Modical Collogo); Dr. A. M. James (physical chemistry at Queen Elizabeth College); Dr. M. H. Quenouille (statistics at the Imperial College of Science and Technology); Dr. E. A. Ash (electrical engineөring at University College). The following titles have been conferred: professor of pædiatrics, on Dr. J. P. M. Tizard, in respect of his post at the Institute of Child Health; professor of social institutions, on Mr. O. R. McGregor, in respect of his post at Bedford College; reader in physics, on Dr. D. W. O. Heddle, Dr. C. Henderson and Dr. R. E. Jennings, in respect of their posts at University Colloge; reader in biochemistry, on Dr. M. W. Neil, in respect of his post at the London Hospital Medical College; reader in human environment, on Dr. I. W. Cornwall, in respect of his post at the Institute of Archæology.

Southampton

Prof. G. M. Lilley, professor of fluid dynamics at the College of Aeronautics, Cranfield, has been appointed to the chair of aeronautics and astronautics. Mr. P. Ham. mond, Follow and director of studies in electrical sciences in Pembroke College, Cambridge, has been appointed to the chair of electrical power engineering. Dr. H. B. Griffiths, senior lecturer in mathematics in the University of Birmingham, has been appointed to the second chair of pure mathematics. Mr. J. H. Smith, lecturer in social science in the London School of Economics, has been appointed to the chair of sociology. Prof. E. J. Richards, professor of aeronautics in the University, has been appointed to the new chair of applied acoustics and the directorship of the Institute of Sound and Vibration Research. The following appointments to lectureships have been made: Dr. R. A. East (aeronautics and astronautics); Dr. R. Baker, Dr. M. C. Flowers, Dr. N. B. H. Jonathan, Mr. J. M. Mellor and Dr. J. S. Wood (chemistry);
Dr. M. E. Barton and Dr. B. S. Smith (civil engineering); Mr. J. D. E. Beynon (electronics); Mr. E. W. Haddon (mathematics); Dr. J. G. McEwen (physics); Dr. A. Crowe (physiology and biochemistry); Dr. T. Priede and Mr. P. L. Tanner (sound and vibration research); Miss D. M. Shepherd (sociology and social studies).

\section{Announcements}

Dr. Frank Doluin, chief turbine engineer, C. A. Parsons and Co., Ltd., has been awarded a Thomas Hawksley Gold Medal by the Institution of Mechanical Engineers, for his paper, "Some Design Problems Arising in the Development of Very Large High-speed Turbines". The award, established in 1908, commemorates the eminent engineer, Thomas Hawksley, who was president of the Institution in 1876 and 1877, and is given for the best paper published by the Institution in the year.

THE Bulletin Science East to West, formerly known as Russian Technical Literature, issued by the Directorate for Scientific Affairs of the Organization for Economic Co-operation and Development, covers scientific and technical literature from East Europe, the U.S.S.R., and China and Japan. The January 1964 issue (No. 13) includes an article on the production and utilization of energy in the U.S.S.R., a list of recently published translations of books from Russian and details of courses available in the Russian language.

A Discussion meeting on "The Future of Chemical Publications" will be held by the Chemical Society in the University of Nottingham during September 22-24. Further information can bo obtained from the General Secretary, the Chemical Society, Burlington House, Piccadilly, London, W.1.

A symposium on "Hydroxycinnamic Acids and Related Compounds", arranged by the Phytochemical Group (formerly the Plant Phenolics Group), will be held at the University of Sheffield during September 22-23. Further information can be obtained from A. H. Williams, Research Station, Long Ashton, Bristol.

A screntific meeting of the Hospital Physicists' Association will be held, to celebrate the twenty-first anniversary of its foundation, at St. Bartholomew's Hospital during Sэptember 24-26. Further information can be obtained from Miss K. Smith, Hospital Physicists' Association, 6 Paddington Street, Marylebone High Street, London, W.1.

A CONFERENCE on "Many-body Problems", arranged by the Institute of Physics and the Physical Society, will be held in the University of Manchester during September 22-24. The programme will include sessions on manybody problems in: atomic physics; molecular physics; nuclear physics; solid-state physies; polymers; liquids. tration Assistant, Institute of Physics and the Physical Society, 47 Belgrave Square, London, S.W.I.

A sHoR'T course on "Practical Noise Control", arranged by the Institute of Sound and Vibration Research, will be held in the University of Southampton during September 16-18. The course will consist of ten lectures, supported by laboratory demonstrations, and will cover acoustics, noise measurements, subjective assessments, technical principles of noise control and medical and legal implications. Forms of application and further information can be obtained from Dr. T. Priede, Institute of Sound and Vibration Research, the University, Southampton.

Erratum. The author of the book Planetary, Lunar, and Solar Positions A.D. 2 to A.D. 1649 at Five-day and Ten-day Intervals, which was reviewed by Dr. R. $H$. Garstang on p. 943 of the June 6 issue of Nature, is Bryant Tuckerman and not Bryant Zuckerman as published. 